\section{Eosinophilia in Patients Infected with the Human Immunodeficiency Virus}

\author{
A. Tietz ${ }^{1}$, L. Sponagel ${ }^{1}$, P. Erb ${ }^{2}$, \\ H. Bucher ${ }^{1}$, M. Battegay ${ }^{1}$, W. Zimmerli ${ }^{3 *}$
}

The prevalence and significance of peripheral blood eosinophilia in patients infected with the human immunodeficiency virus (HIV) were evaluated. Fifteen of 119 consecutive patients had absolute eosinophil counts of $>450 / \mathrm{mm}^{3}$. During a mean follow-up period of 419 days eosinophilia could be identified as secondary to a parasitic infection in only one patient. Correlation with disease stage showed a higher rate of advanced disease in patients with absolute eosinophilia. In a multivariate regression analysis, only low CD4+ cell counts, not the CDC disease stage or the use of antiretroviral therapy or primary prophylaxis, contributed significantly to the prevalence of eosinophilia. It is concluded that expen-sive laboratory investigations in asymptomatic patients with advanced-stage HIV disease are neither necessary nor cost effective.

The occurrence of peripheral blood eosinophilia in patients with human immunodeficiency type 1 (HIV-1) infection has been described previously (1-4). Our daily clinical work suggested that eosinophilia is more common in late-stage infection. Previous retrospective studies have shown either no significant difference in its incidence as related to various disease stages $(1,2)$ or a strong association with advanced disease $(3,5)$.

The major hypotheses for an increased prevalence of peripheral blood eosinophilia in advanced HIV-1 infection include the Th1-Th2 shift of HIV-infected CD4+ lymphocytes, associated with higher levels of interleukin- 4 and -5 and a subsequent increase in immunoglobulin $\mathrm{E}$ ( $\mathrm{IgE}$ ) levels $(5-8)$; parasitic disease not detectable by routine

\footnotetext{
${ }^{1}$ Medical Outpatient Clinic ${ }^{2}$ Institute of Medical Microbio$\operatorname{logy}$, and ${ }^{3}$ Division of Infectious Diseases, University Hospitals Basel, Petersgraben 4, CH-4031 Basel, Switzerland.
}

laboratory methods (4); the infection of CD4+ receptor-positive eosinophils by HIV (since eosinophils are able to produce their own growth factor) $(9,10)$; and the numeric decline of other blood cell lines, leading to a reactive proliferation of eosinophils (11). The aim of this study was to evaluate the prevalence, possible etiology, and correlation with demographic and biologic variables of eosinophilia in HIV-infected patients.

Materials and Methods. We performed a retrospective analysis of charts from 119 Caucasian HIV-1-positive patients who were monitored in a prospective cohort study (the Swiss HIV Cohort Study) at our center. Semiannual follow-up visits included a history and physical examination, complete blood cell counts, lymphocyte differentiation, chemograms, serologic assays, and, if necessary additional diagnostic tests.

Peripheral blood eosinophilia was defined as an absolute eosinophil count of $>450 / \mathrm{mm}^{3}$ on at least two subsequent measurements. No specific routine program for the investigation of eosinophilia is used at our clinic, but all evaluations included analysis of multiple stool samples and serologic tests for common HIV-associated parasites as well as skin biopsies in a few cases with concurrent dermatosis. Basic features of the patients with eosinophilia were identified and compared to those of the control subjects. The 15 case subjects were then paired in a 1:1 fashion with an HIVpositive control group matched for age, sex, transmission mode, and stage of disease. Levels of interleukin-4, interleukin-5, interferon- $\alpha$, and $\mathrm{IgE}$ were measured in serum samples of both groups with modified enzyme-linked assays $(12,14)$. Serum samples for determination of cytokine profiles and IgE levels were collected at the time of detection of eosinophilia.

Results underwent univariate and multivariate regression analysis $(p<0.05)$ with a statistical software program (SPSS for Windows, Version 6.0; SPSS, USA).

Results and Discussion. Of 119 subjects evaluated $15(12.6 \%)$ had absolute eosinophilia (range, 451-2940/ $\mathrm{ll}$; median, $720 / \mu \mathrm{l}$ ). Intergroup comparison showed a significantly higher proportion of patients with low CD4+ cells and CDC disease stage $C$ in the group with eosinophilia. Table 1 summarizes the characteristics of both groups. Patients with eosinophilia were significantly older, and a higher proportion was using antiretroviral medication, which is consistent with the increased prevalence of advanced-stage disease in 
Table 1: Characteristics of HIV-positive patients with and without eosinophilia.

\begin{tabular}{|c|c|c|c|}
\hline Characteristic & $\begin{array}{l}\text { Patients with eosinophilia } \\
\qquad(n=15)\end{array}$ & $\begin{array}{l}\text { Patients without eosinophilia } \\
\qquad(n=104)\end{array}$ & $P$ value \\
\hline Mean age (years) & 45.9 & 36.3 & $0.015^{a}$ \\
\hline Male & $13(86.7 \%)$ & $75(72.1 \%)$ & ns \\
\hline Mean duration of HIV seropositivity (years) & 6.4 & 6.3 & ns \\
\hline History of asthma & 0 & $2(1.9 \%)$ & ns \\
\hline History of allergy/atopy & $4(19.1 \%)$ & $17(16.3 \%)$ & ns \\
\hline Eczema & $8(38.1 \%)$ & $23(22.1 \%)$ & ns \\
\hline Folliculitis & $6(28.6 \%)$ & $16(15.3 \%)$ & ns \\
\hline Tissue eosinophilia & $1(4.8 \%)$ & 0 & ns \\
\hline Intestinal parasites in stool samples & $1(4.8 \%)$ & $4(3.8 \%)$ & ns \\
\hline $\begin{array}{l}\text { CDC disease stage }{ }^{b} \\
\text { A } \\
\text { B } \\
\text { C }\end{array}$ & $\begin{array}{l}1(6.7 \%) \\
5(33.3 \%) \\
9(60.2 \%)\end{array}$ & $\begin{array}{l}28(26.9 \%) \\
52(50.0 \%) \\
24(23.1 \%)\end{array}$ & $<0.005^{\mathrm{c}}$ \\
\hline $\begin{array}{l}\text { CD4+ cell count } \\
>500 / \mu \mathrm{l} \\
200-500 / \mu l \\
<200 / \mu \mathrm{l}\end{array}$ & $\begin{array}{c}1(6.6 \%) \\
2(13.3 \%) \\
12(80.0 \%)\end{array}$ & $\begin{array}{l}10(9.6 \%) \\
45(43.3 \%) \\
49(47.1 \%)\end{array}$ & $0.017^{\mathrm{c}}$ \\
\hline $\begin{array}{l}\text { Transmission mode } \\
\text { Homosexual } \\
\text { Intravenous drug abuse } \\
\text { Heterosexual } \\
\text { Blood products }\end{array}$ & $\begin{array}{l}8(53.3 \%) \\
3(20.0 \%) \\
3(20.0 \%) \\
1(6.7 \%)\end{array}$ & $\begin{array}{l}39(37.5 \%) \\
46(44.2 \%) \\
19(18.3 \%) \\
0\end{array}$ & $\begin{array}{l}\text { ns } \\
\text { ns } \\
\text { ns } \\
\text { ns }\end{array}$ \\
\hline Antiretroviral therapy ${ }^{d}$ & $11(73.3 \%)$ & $44(36.9 \%)$ & $0.025^{\mathrm{C}}$ \\
\hline Primary PCP prophylaxis ${ }^{e}$ & $8(53.3 \%)$ & $39(37.5 \%)$ & ns \\
\hline
\end{tabular}

a Levene's t-test for equality of variances.

b CDC disease stage definition: A, asymptomatic; B, minor opportunistic diseases; C, acquired immunodeficiency syndrome;

Mantel-Haenszel test for linear association.

d Antiretroviral drugs used were zidovudine, didanosine, and zalcitabine.

e Cotrimoxazole or dapsone/pyrimethamine.

ns, not significant; PCP, Pneumocystis carinil pneumonia.

this group. The results of the multivariate logistic regression analysis indicate that a $\mathrm{CD} 4+$ cell count below $200 / \mu \mathrm{l}$ is significantly associated with an increased risk for peripheral blood eosinophilia (Table 2). The use of antiretroviral therapy (reverse transcriptase inhibitors: zidovudine, didanosine, or zalcitabine) did not contribute to the model significantly, in contrast to the findings from the univariate analysis. The duration of seropositivity was similar in both groups, indicating coincidence between rapid progression and eosinophilia.

On retrospective evaluation, one patient had severe eczema and erythrodermia with tissue eosinophilia. He also had a history of travel in the

Table 2: Multivariate analysis of variables associated with peripheral blood eosinophilia in HIV-positive patients (Cox proportional hazards model).

\begin{tabular}{lccc}
\hline Variable & Adjusted risk ratio & $95 \% \mathrm{Cl}$ & $\mathrm{P}$ value \\
\hline CD4+ cell count $<200 / \mu \mathrm{l}$ & 2.81 & $1.09-7.24$ & 0.03 \\
Disease stage C & 1.82 & $0.95-3.51$ & 0.07 \\
Antiretroviral therapy $^{\mathrm{a}}$ & 0.62 & $0.29-1.34$ & $\mathrm{~ns}$ \\
Primary PCP prophylaxis $^{b}$ & 2.09 & $0.98-4.89$ & 0.09 \\
\hline
\end{tabular}

a Zidovudine, didanosine, or zalcitabine.

b Cotrimoxazole or dapsone/pyrimethamine.

ns, not significant; PCP, Pneumocystis carinit pneumonia. 
tropics and transient Trichuris trichiura infection detected by stool examination. During a median follow-up time of 419 days (range, 89-1769 days), we detected no other cases of secondary eosinophilia. Therefore, we propose that in the absence of epidemiologic, anamnestic, or clinical symptoms indicating parasitic disease, allergic disorders, neoplasms, or skin disease, three stool samples for bacteria, ova, and parasites are sufficient for evaluation. In view of our findings, a complete series of tests including chest radiographs, abdominal ultrasound, serologic evaluation for parasitic disease, or even bone marrow aspiration is unnecessary.

Interleukin-4, interleukin-5, and interferon- $\gamma$ levels were undetectable in both groups, i.e., subjects with eosinophilia and the matched control subjects. There was no statistically significant difference between the groups in immunoglobulin $\mathrm{E}$ levels $(20.6 \pm 12.9 \mathrm{ng} / \mathrm{ml}$ in eosinophilic patients vs. $13.0 \pm 7.5 \mathrm{ng} / \mathrm{ml}$ in patients without eosinophilia; $p=0.32$ with the two-tailed Student's t-test).

As to the possible reasons for the higher rate of eosinophilia in patients with late-stage disease, our data were not able to reproduce any cytokine modulations attributed to the Th1-Th2 shift hypothesis. This finding may be due to our use of serum instead of supernatants of $T$ cells for our analyses. Patients with eosinophilia had IgE levels similar to those found in the control subjects which precludes us from interpreting eosinophilia in HIV infection as indicative of an allergic reaction. Nevertheless, since severely immunocompromised patients are more likely to receive multidrug regimens for the treatment of HIV infection and diseases associated with it, eosinophilia could denote a reaction to multiple-drug therapy.

In conclusion, the prevalence of eosinophilia in patients with HIV-1 infection was $12.6 \%$; more than two-thirds of these patients were severely immunocompromised. There was no significant elevation of serum $\mathrm{IgE}$ levels, suggesting a nonallergic cause. Our results indicate that eosinophilia is most probably associated with HIV infection when epidemiological or clinical features indicative of other conditions with eosinophilia are absent.

\section{Acknowledgement}

These data were presented in part as a poster at the XIth International Congress on AIDS, Vancouver, Canada, 7-13 July 1996.

\section{References}

1. Sanchez-Borges M, Orozco A, DiBagio E, Tami I, Suarez-Chacon R: Eosinophilia in early-stage HIV-infection. Journal of Allergy and Clinical Immunology 1993, 92 : 494-495.

2. Van der Graaf W, Borleffs JCC: Eosinophilia in patients with HIV-1 infection. European Journal of Haematology 1994, 52: 246-247.

3. Caterino DeAranjo C: HIV-1 infection and eosinophilia. Immunology Today 1994, 15: 498-499.

4. Wardlaw AJ: Eosinophils in the 1990s: new perspectives in their role in health and disease. Postgraduate Medical Journal 1994, 70: 536-552.

5. Smith KJ, Skelton HG, Drabick JJ, McCarthy WF, Wagner KF: Hypereosinophilia secondary to immunodysregulation in patients with HIV-1 disease. Archives of Dermatology 1994, 130: 119-121.

6. Clerici M, Shearer GM: A Th1 $\rightarrow$ Th2 switch is a critical step in the etiology of HIV infection. Immunology Today 1993, 14: 107-111.

7. Clutterbuck EJ, Hirst EMA, Sanderson CJ: Human interleukin- 5 regulates the production of eosinophils in human bone marrow cultures. Blood: 1989, 73: 1504-1512.

8. Freedman AR, Gibson FM, Fleming SC, Spry CJ, Griffin GE: Human immunodeficiency virus infection of eosinophils in human bone marrow cultures. Journal of Experimental Medicine 1991, 174: 1661-1664.

9. Lucey DR, Dorsky DI, Nicholson-Weller A, Weller P: Human eosinophils express CD4 protein and bind HIV-1 gp120. Journal of Experimental Medicine 1989, 169: 327-332.

10. Steffen MJ, Ebersole JL: Sequential ELISA for cytokine levels in limited volumes of biological fluids. Biotechniques 1996, 21: 504-509.

11. Cohen AJ, Steigbigel RT: Eosinophilia in patients infected with the human immunodeficiency virus. Journal of Infectious Diseases 1996, 174: 615-618.

12. Sanderson $\mathrm{CJ}$ : Interleukin-5, eosinophils and disease. Blood 1992, 79: 3101-3109.

13. Sample S, Chernoff DN, Lenahan GA, Lanahan GA, Serwonska MH, Rangi S, Sherman JW, Sooy CD, Hollander $\mathrm{H}$, Goetzl EJ: Elevated serum concentrations of IgE antibodies to environmental antigens in HIV-seropositive male homosexuals. Journal of Allergy and Clinical Immunology 1990, 86: 876-880.

14. Kemeny DM, Richards D, Durnin S, Johannson A: Ultrasensitive enzyme-linked immunosorbent assay (ELISA) for the detection of picogram quantities of $\mathrm{lgE}$. Journal of Immunological Methods 1989, 120: 251-258. 